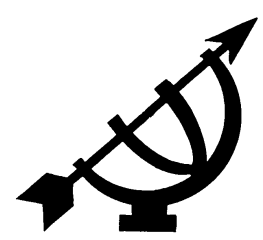

\title{
Globalisation in African and Biblical perspectives
}

\author{
Pius Oyeniran Abioje \\ Department of Religions \\ University of Ilorin \\ ILORIN \\ Nigeria \\ E-mail: poabioje@yahoo.com
}

\section{Abstract \\ Globalisation in African and Biblical perspectives}

The main focus of this article consists of unraveling the meaning of globalisation in terms of its purpose, and determining why many Africans appear to view its goals skeptically. The study is done from a Christian theological perspective, thus the conformity of globalisation to Biblical worldview is also examined. The data were gathered mainly through library consultation. Theoretically, the study is expository and critical. One discovers that globalisation conforms with Afro-Biblical worldviews, but only in so far as it embraces unstinting love of God and the neighbour, universal justice, mercy and compassion. The world itself seems to be realising how interdependent human life is. It is, however, suspected that the owners of the multinational corporations who are drumming up globalisation, have ulterior motives. It was noted that Western institutions, represented by multinationals, have always sought ways to exploit Africa and the Third World in general. At the same time, there is the realisation that no external enemy could succeed without the cooperation of some internal enemy, and there have always been African rulers who collaborate with foreigners to exploit the continent. It is explained that Africa can fare better with globalisation if the leaders are ethically and prudentially upright.

\section{Opsomming}

\section{Globalisering volgens Afrika en Bybelse perspektiewe}

Hierdie artikel fokus hoofsaaklik op die ontleding van die betekenis en doel van globalisering en om vas te stel waarom vele inwoners van Afrika klaarblyklik skepties is oor die doel 
van globalisering. Hierdie artikel is uit 'n Christelik-teologiese oogpunt geskryf en dus word die ooreenkoms tussen globalisering en 'n Bybelse wêreldbeskouing ook ondersoek. Die inligting hiervoor is hoofsaaklik verkry uit biblioteekbronne. Teoreties is die artikel verklarend en krities. Dit word duidelik dat globalisering wel met Afro-Bybelse wêreldbeskouing ooreenstem, maar egter net in soverre as wat dit die onvoorwaardelike liefde vir God en die medemens, universele geregtigheid, barmhartigheid en empatie insluit. Dit wil voorkom asof die wêreld wel besef hoe interafhanklik menslike lewe is, maar die vermoede ontstaan egter dat die eienaars van veelvolkige organisasies, wat groot voorstanders van globalisering is, se motiewe nie altyd onbaatsugtig is nie. Dis opmerklik dat Westerse instellings, verteenwoordig deur die veelvolkige organisasies, altyd daarop uit was om Afrika en die Derde Wêreld in die besonder, uit te buit. Terselfdertyd is egter besef dat geen eksterne bedreiging suksesvol kan wees sonder die samewerking van 'n interne vyand nie. Daar was en sal altyd Afrikaleiers wees wat met uitlanders heul om die kontinent uit te buit. Globalisering kan veel beter in Afrika geïmplementeer word indien die leiers meer waarde aan die etiese sou heg en met meer omsigtigheid sou optree.

\section{Introduction}

In 1945, the United Nations Organisation (UNO) was formed as a major attempt at unifying the world and controlling its affairs in a humanised way. The League of Nations that existed earlier did not enjoy as much patronage as the UNO. As Reeder Smith and Lacey Baldwin Smith (1980:117) note: "the League was weak from the beginning: the United States refused to join, and few of the great powers were even members at the same time". On the contrary, even though the UNO was formed originally by 51 member nations, there is hardly any nation in the world today that does not belong to the organisation. Speaking in an interview on the British Broadcasting Corporation (BBC) on 22nd March 2005, Kofi Anan, the UNO's President, stated that the UNO was composed of 191 nations. Mustapha (2007:65) notes: among the highly essential parastatals of the UNO are the World Health Organisation (WHO), the Food and Agricultural Organisation (FAO), the United Nations Children Education Fund (UNICEF), and the World Court (WC). The purpose of this preamble is to indicate that although the idea of globalisation rooted in the acronym "global village", appears to be much recent, the effort at unifying the world dates back to the earliest of times. The concept sounds good, but for some reasons 
discovered in the course of this study, many Africans seem scared of the globalisation slogan as currently propagated.

\section{Focus of the article}

The overall focus of this article is to examine the concept of globalisation in terms of its purpose, and why many Africans appear to be skeptical of its goals. Since this artcle constitutes an exercise in Christian theology, the Biblical view of globalisation is presented towards committing people to a genuine form of globalisation. The article is presented under the following sub-headings: The concept of globalisation, a Biblical view of globalisation, globalisation in African perspective, ending with the conclusion.

\section{The concept and origin of globalisation}

Most obviously, the word globalisation is derived from the term globe which, according to the Webster's Encyclopedic Unabridged Dictionary of the English Language (1996), connotes "anything more or less spherical", but "used specifically for 'the planet Earth' when preceded with the article 'the'". Thus, to globalise is to form into a globe or unify into a single spherical mass. In short, the concept of the global village or globalisation implies that the whole world should see itself as a single society, with a common destiny.

\subsection{The origin of globalisation}

Historically speaking, globalisation is said to have started as a gradual process. According to a report by the Economic Community of West African States (Anon., 2003:34), the concept emerged in the last decade of the twentieth century when observers began commenting on how intertwined the world was becoming. The report has it that the root of globalisation should be traced to the early "European discoveries which saw European powers reach out to the various continents", and "that the early globalisation process gave birth to the trans-Atlantic trade from Africa to the Americas to Europe". As an advancement, as the report states: "We now live in a world unfolding on our television screens or computer terminals as they happen and impact on our lives as never before." Consequently, "consumption patterns, culture, eating habits, and diseases are no longer isolated to places where they originate". With particular reference to Africa, it reads that:

There have been dramatic shifts in movement of people from Africa to all corners of the world. African sportsmen and women, 
professionals and technicians ply their trades in all corners of the world, as everywhere is just a plane flight away.

Globalisation would thus seem to have cultural, political, social, religious, economic and other possible implications. But this article focuses on its economic aspect, much more than any other consideration. It is felt that the categorisation of Africa as basically a Third World continent is anchored on economic factors of underdevelopment. That is beside the fact that in the findings of this writer, globalisation is technically conceived fundamentally in economic terms. Bernard Joinet (2000:18) notes, for instance, that "nowadays, the liberal market economy is practically the only way of doing business, worldwide, except in Cuba and North Korea", and that "this is what is called the globalisation of the market economy, with its positive and negative effects". Similarly, Khalid Mahmood Shaikh (2006:5) remarks that "science and technology have revolutionised the media and means of communications", and that "made the world a global village and market".

\subsection{Economics in human life}

One would think that although not all, most of human activities are geared toward some economic end, including sports and what is referred to as the entertainment industry, sex-related works, et cetera. Even in religious matters, the Yoruba of Western Nigeria would say, for instance, that money is the vehicle of the gospel (owo ni keke ihinrere), which means that the gospel cannot be spread or propagated without money.

\subsection{The economicocentric nature of globalisation}

Many scholarly opinions buttress the economic stress on globalisation as this article reveals. That is explicit in the words of Joseph Stiglitz (2003:ix), a former Chief economist at the World Bank and winner of the Nobel prize for economics 2001. He notes:

While I was at the World Bank, I saw firsthand the devastating effect that globalization can have on developing countries. I believe that globalization - the removal of barriers to free trade and the closer integration of national economies - can be a force for good and that it has the potential to enrich everyone in the world, particularly the poor. But I also believe that if this is to be the case, the way globalization has been managed, including the international trade agreements that have played such a large role in removing those barriers and the policies 
that have been imposed on developing countries in the process of globalization, need to be radically rethought.

With particularly reference to Africa, the point is concretised in the experience of Robert Guest regarding why globalisation may need to be radically rethought. Guest (2005:16) notes that :

In the energy-sapping heat of Uganda, I watched women bent double to tend rows of flowers destined for exports. They toiled and sweated long hours for a pittance so that pampered Westerners could buy roses all year round. Bono, the Irish rock star and conspicuous campaigner for worthy causes, was also watching. One might have expected him to protest at this scene of back breaking drudgery. Instead, he said it represented 'globalization at its best'.

Thus, the word globalisation as a coinage or terminology tends to evoke economic indices much more than any other consideration of human endeavour or enterprise. Its negative implication for Africa's economic health has also been exposed in a nutshell in these quotations.

\section{A Biblical view of globalisation}

Apparently, neither the Jewish Scripture (Old Testament), nor the New Testament, which is the special Christian Scripture contains the word globalisation as a nomenclature. Yet, each of the two parts of the Bible can be seen to entail a form of globalisation as an ideal principle, when the term means that all human beings should view themselves as a people and the world as a universe belonging to all men and women, sharing a common destiny, and facing the same life's ups and downs. As Joseph Stiglitz (2002:xv) notes:

The barbaric attacks of September 11, 2001, have brought home with great force that we all share a single planet. We are a global community, and like all communities have to follow some rules so that we can live together. These rules must be and must be seen to be - fair and just, must pay due attention to the poor as well as to the powerful, must reflect a basic sense of decency and social justice.

That refers to the airplane hijackers who diverted the airplane to hit the World Trade Centre in New York, thereby killing all those on board and most of those inside the building. The individuals who paid with their lives, hailed from various nations. 


\subsection{Globalisation and context}

Philosophically and theologically speaking, the assumption is here that whatever meaning the Western world may attach to globalisation, it should be possible to discuss globalisation relatively from other perspectives, such as the African and Biblical viewpoints. That seems to be what many scholars refer to as study-in-context or contextual study. Ruele (2003:78) notes that, "we are all aware that theology is done in the context in which people live", and "it is the prevailing conditions that shape the nature of the theology that emerges in a particular context and at a given time in the lives of the people". On the origin of contextual theology, Nicholls (1998:165) notes that:

The origin of the term contextualization is credited to Shoki Coe and Aharoan Sapsezian, directors of the Theological Education Fund of the WCC in their 1972 report, Ministry and Context. They suggested that the term 'contextualization' implies all that is involved in the term 'indigenization' but goes beyond it to take account of the process of secularity, technology and the struggle for human justice which characterized the historical moment of nations in the third world.

To contextualise globalisation in Biblical perspective, one would endeavour, theoretically, to reduce the paradigms to Biblical categories.

\subsection{Human origin in Biblical account}

The Old Testament presents a story to the effect that the world is created by only one God, and all human beings descended from Adam and Eve who were the primogenitor couple created by God (Gen. 1-2). The theory that all human beings originated from a single couple is termed monogenism (Brown, 1990:34 ff.). Referring to Adam and Eve as real human beings is found in St. Paul who, in some of his epistles, speaks of the first and second Adam (1 Cor. 15:45; Tim. 2:13), maintaining that all human beings die in the first Adam (1 Cor. 15:22), while they regain their lives in the Second Adam (1 Cor. 15:15). Dying in the first Adam is about the doctrine of the original sin, and that forms the basis on which many churches object to the assertion that the story of Adam and Eve is fictional. With particular reference to the Roman Catholic Church, Daly (1996:673), while explaining what is understood by monogenism as opposed to polygenism, notes that: 
... the doctrine that all human beings are descended from a single couple, the 'Adam and Eve' of Gen. 2-3. In the Encyclical Humani generis (1950), Pius XII taught that it was not at all apparent that any view which denied this common origin of all members of the human race could be reconciled with the church's teaching on original sin.

A non-Catholic, Warfield (1988: 258), likewise notes that:

It is because all are one in Adam that in the matter of sin there is no difference, but all have fallen short of the glory of God (Rom. III - 22f), and as well that in the new man there cannot be Greek and Jew, circumcision and uncircumcision, barbarian, Scythian, bondman, freeman; but Christ is all and in all (Col. III. 11).

Thus, in principle, the Bible entails a form of globalisation in a divine and humane sense. Indeed, there is the believe that the disunity visited on humanity by God, which was caused by the conspiracy surrounding the tower of Babel (Gen. 11:1-9), has been atoned-for by Christ, notwithstanding the subsistence of diversity of language, culture, and geographical location (Shields, 2004:166).

\subsection{The Biblical paradigm of love}

Of equal relevance is the fact that both the Old Testament and the New Testament enjoin love of God and neighbour, as a sine qua none of faith. A neighbour, in Biblical understanding, is not an ethnic, tribal or clannish term. It refers to whoever one might be in the position to help or assist. This fact may not be too obvious in the Old Testament. As Peschke (1981:174) notes, "there is no mention of love that is exercised towards non-Israelite foreigners and heathen nations until the rabbinical writings of the second century after Christ". Yet, every person who is created in imago Dei is said to be endowed with the spirit of God (Gen. 1:27), and is expected to love fellow human beings as indiscriminately as God loves them. Scripturally speaking, there seems to be no doubt that God's interest centres on brotherly concern, altruism, justice, generosity, love and virtuous living. It is stated, for instance, that: "to act virtuously and with justice is more acceptable to Yahweh than sacrifice" (Prov. 21:3), and God is quoted as saying: "Learn to do good, search for justice, help the oppressed, be just to the orphan, plead for the widow" (Is. 1:17). Another crucial quotation that is attributed to God, and cited on two occasions by Jesus Christ is: "I desired mercy, not sacrifice" (Hos. 6:6; Matt. 9:13 and 12:7). Obviously, if globalisation is to conform with Biblical worldview, it cannot but incorporate these 
virtues, without which globalisation itself may not stand the test of time.

\subsection{Toward a Biblical theology of globalisation}

Jesus can be said to endorse the Old Testament teaching, not only when $\mathrm{He}$ is quoted as saying that $\mathrm{He}$ has not come to abolish the Law and the Prophets (Matt. 5:17), but also when He explains that the essential matter of the Law is love of God and neighbour (Matt. 22:40 and Luke 10:25-28). He also identifies "justice, mercy and good faith" as the "weightier matters of the Law" (Matt. 23:23). These virtues seem to be indispensable to a holistic form of globalisation that can conform with the Biblical worldview. Turaki $(2001: 217,232)$ notes that:

All creation and humanity are united together in God's universal act of creation. This unity of divine creation establishes the commonality of all God's creatures ... Similarities and commonalities among world religions and cultures reflect the common origin of humanity.

On page 182 of the same book, he notes about the Biblical concept of love, that:

It is the action of love, which brings about peace. For this reason, it is very important that we describe that action which brings about peace, which is divine love. God's love is also the founding principle and basis of reconciliation and redemption.

Generally speaking, that seems to be the basis of globalisation or human solidarity in Biblical perspective. The key terms are God, creation, love and peace: incompatible words include: exploitation and any form of wicked and uncompassionate acts, and injustice that are said to characterise globalisation as propagated currently.

\section{Globalisation in African perspective}

Essentially, there seems to be similarity between the Biblical and African views of globalisation when it is anchored on the belief in God as the sole Creator, Ruler and Sustainer of existence. Fuller (2001:22) aptly notes that "virtually all of Africa believes in a Supreme God who created everything else (the middle powers, people, animals, and the physical universe)." That seems identical, substantially, with the Biblical view that was expressed hitherto. 


\subsection{Creation in African aetiology}

Equally similar is the African ethical view of reality. Awolalu and Dopamu (2005:67 ff.), in their study of traditional religion in West Africa, note that "we know from the various accounts that man has a moral nature, a spiritual quality through the essence of being given to him by God", and "although some stories do not say more than that God made man, the emphasis is on the fact that man did not come into being of his own accord, but originated in consequence of a Supreme Maker".

\subsection{Life and love in Africa}

With particular reference to love, which is said to be the leaven of life in Biblical perspective, Ehusani (1992:2) notes with regard to Africa, that:

I looked back with nostalgia at the traditional African humanistic world view which is encapsulated in the Ebira name 'ozovehe' meaning 'the human person is life'. This world view which is expressed in the traditional African's love for children, for the family, for harmony or wholesome personal relations, for community and for hospitality, gave meaning and purpose to traditional life and characterized the African 'humanistic'.

It can thus be said that, as with the Biblical worldview, globalisation conforms with African perspective, holistically speaking, should it embrace humane virtues, which are encapsulated in love of God and neighbour, in charity and hospitality, without which a genuine form of human relationship or globalisation may never emerge. lyekolo (2006:122) notes that:

The Holy Bible is the word of God and is explicit on the obligations of man to become acceptable to Him. The Holy Koran teaches the ways to get to heaven through the five pillars of faith and belief in the teachings of Prophet Mohammed. The traditionalists preach good deeds on earth as a passport to heaven.

This view tends to conform with the course of African Christian theology of inculturation, which is contextual in orientation, and based on the conviction that African Traditional Religion (ATR) has a lot in common with Biblical doctrines and faith tenets, with particular reference to ethical concerns. 


\subsection{Africa's experience of unity in diversity}

Over and above what was previously mentioned, many scholars have noted the fact that in principle, ATR naturally accommodates any other religion and people. As Turaki (2001:111) notes, for instance, "Africa is a broad society of multi-cultures, multi-religions and multi-values and truth claims and has over the centuries developed a concept of limited pluralism that can accommodate, tolerate and domesticate these differences." He notes further that "new gods and new values can be accommodated or be allowed to co-exist so long as none is threatened or denied the right to exist".

\subsection{Instinct for globalisation}

One would think that what makes globalisation possible is openness to life and human capacity to love responsibly and hospitably. Parshall (2003:98) notes that, "all religions teach love", and "though the interpretation will vary from society to society, love is regarded as a positive quality among all of mankind". Of course beyond generalisation, as hitherto quoted and explained, ATR enjoins indiscriminate love of neighbour and fraternal co-existence. Therein lies the motivation for globalisation in African worldview. God has, after all, created the world with a variety of human beings, other animals, fishes, birds, and non-human organic beings, such as trees, grasses, et cetera.

\subsection{Africa's historical relationship with the West}

Nevertheless, many right-thinking Africans seem to view globalisation skeptically for a number of reasons. For one thing, the concept has emanated from the West which colonised and exploited in the past, and in many areas has continued to exploit the Third World, with particular reference to Africa. As Ekwuru (2000:3) notes, for instance:

Africa and Africans everywhere still live with the deep wounds of centuries of slave trade, colonisation, looting, and raping of values and cultures by the Western world. The worse is that even in the contemporary world, the West has not 'forgiven' Africans for what and where they are.

The point is suggestive of the fact that some or many Africans are historically scared for the economic antics of the West. Newton (1992:541) observes that: 
After the British had outlawed slavery in 1807, they began looking for other ways to exploit Africa, financing the exploration of inland waterways and other means for opening up trade. During the scramble for Africa in the late 19th century, Britain sent armies to gain political control over Nigeria.

Thus, it would seem that the West is notorious in its perpetual quest for exploitation of Africa. On the same page, Newton presents a typical way in which the British economically exploited and impoverished Africa. He notes, for instance, how tin was a well-organised industry in the central plateau area of Nigeria, around Jos, and how over 50 foreign companies came in and took over the Jos mines, employing nearly 40000 tin miners by 1928. "Thus, the British destroyed the thousands of independent tin producers converting them into wage earners with no other means of livelihood." That type of experience seems to continue to trail Africa, and most probably heighten their reservation on "globalisation". Therefore the 1950 s and 1960s witnessed numerous nationalist activities, which eventually resulted in independence for many African nations.

\subsection{The globalisation scare}

With reference to globalisation, it would seem that, not without good reasons, many Africans attribute the economic hardship pervading the continent to Western institutions, such as the International Monetary Fund (IMF), the World Bank, and the World Trade Organisation (WTO). Therefore they become suspicious and scared. The IMF and World Bank are said to persuade African countries to borrow huge amounts of money for the development of their infrastructure and economic ventures. Stiglitz (2002:128) notes that although debt may be inevitable for development, "it is inherently risky", and "IMF strategies, such as capital market liberalization and raising interest rates to exorbitant levels when a crisis occurs, make borrowing even riskier". Most unfortunate, of course, is that many African leaders are said to embezzle the funds and siphon them back into Western banks for safety and secrecy.

Consequently, many African countries now spend a lot of their earnings to service debts that were rarely spent for the good of the people. To be able to repay the loans and the interests, the IMF usually prescribes a Structural Adjustment Programme (SAP) which further drains the people - the governments are advised to remove subsidy from all subsidised goods and services. In the words of Stiglitz (2002:xiv, xv): 
Undoubtedly, some pain was necessary; but in my judgement, the level of pain in developing countries created in the process of globalization and development as it has been guided by the IMF and the international economic organizations has been far greater than necessary ... You won't find hard evidence of a terrible conspiracy by Wall Street and the IMF to take over the world. I don't believe such a conspiracy exists. The truth is subtler. Often it's a tone of voice, or a meeting behind closed doors, or a memo that determines the outcome of discussions.

One would think that pre-determined "outcome of discussions" implies conspiracy. No wonder concerned Africans, such as Samuel Kobia, are of the opinion that the campaign for the cancellation of the debts may not work unless the immorality involved in the contracting of the debts is exposed. In the words of Kobia (1998:10), "alongside the campaign for debt cancellation, the church must raise ethical questions about borrowing, lending and spending", and "state in no uncertain terms that structural adjustment policies and programmes and the debt servicing and repaying are unethical as long as they result in massive suffering of the people".

\subsection{Africa in the 21 st century}

Issues are raised about how Africa and some other weak economies became indebted and the humanitarian and ethical difficulties arising therefrom are without doubt very serious, but this trend has not ceased. Many conscientious Westerners who are conscious of the debt scourge, based on the IMF prescribed structural adjustment, express serious concern. Brubaker (2002:5) notes, for instance, that:

Those of us in the North need to take seriously the claim of people from the South that structural adjustment programmes and the larger neoliberal agenda are forms of recolonization. The reality they experience contrasts sharply with the rhetorical commitment of the US and other Northern countries to democracy, human rights and women's rights.

Thus, many Africans certainly feel that the West has continued to control human life in most African countries. What of the many industries, products and services that are dominated by Western forces? Western-based multinational corporations engage in the selling of food and drink items, engines, including generators and rechargeable lamps; they build roads, and dominate other vital areas of modern existential needs. This, coupled with strangulating craftiness, put the Western and Asian status quo in the position to 
make or break African rulers. It is believed that any aspirant who will not cooperate with the multinational corporations cannot become the president of any African nation. Unfortunately, what Babu (1976: $315 \mathrm{ff}$.) noted a long time ago remains true in the view of this writer, that:

With all due respect, it is difficult to imagine, apart from one or two honourable exceptions, any of the present leaders who is capable of standing up for the genuine rights of his people, knowing that these rights are of necessity directly opposed to the interests of imperialism. And yet such a stand is necessary if we are to really fulfil our obligation as leaders, otherwise we have no right to impose our leadership on the people.

Of course, there is hardly any doubt that with good leadership, Africa can be as progressive as any developed continent in the world. A lot can be achieved with an appropriate political will and determination, pushed and driven by competent and upright leaders.

\subsection{Globalisation as a gimmick}

With the foregoing antecedents, it might seem that the Western world has a game-plan which is to float the idea of globalisation, so as to create the impression that all human beings are one people and everywhere is home to everybody, in order to be able to advance their trades as unhindered as possible. Not surprisingly, then, many knowledgeable and conscientious Africans, like their counterparts worldwide, view globalisation and the concept of global village as a hoax, a domination ploy. Writing as "heirs of the Biblical prophets who summon us 'to do the right and to love goodness' (Matt. 6:8)", the National Conference of Catholic Bishops of the United States of America (1986, VI:121, 122) warn that unless conscious steps are taken against inequity, to protect human dignity and foster human solidarity, conflicts are bound to arise. They hold that unity of the human family (which is supposedly expressed in the concept of globalisation) cannot stand unless the treasures of the earth are equally shared, to pursue the international common good, as well as the good of every nation, and the imperative of distributive justice.

\subsection{The culpability of African leaders}

In other words, globalisation, as it is currently run, is seen by many knowledgeable and conscientious people as an unfavourable design for poor nations. The powerful world leaders who are mostly Westerners would seem to have secured international trade agree- 
ments and policies which are detrimental to under-developed nations. As Stighte (2002:xv) notes:

Today, few - apart from those with vested interests who benefit from keeping out the goods produced by the poor countries defend the hypocrisy of pretending to help developing countries by forcing them to open up their markets to the goods of the advanced industrial countries while keeping their own markets protected, policies that make the rich richer and the poor more impoverished - and increasingly angry.

Unfortunately, many African leaders are not unculpable or blameless. A Yoruba adage has it that without the cooperation or collaboration of a thief within, no thief from without can succeed. And so it has always been that foreign exploiters more often than not engage the collaboration of powerful insiders for maximum exploitation of targeted societies. In respect of the slave trade that ravaged Africa, for instance, Fajana and Biggs (1967:144) note that "a profit was not only made by those directly engaged in the trade, but also by African chiefs whose territory was affected", as they "issued licenses to traders and exacted tolls on slaves". There seems to be no indication that the situation has changed with regard to bad leadership and their foreign partners.

\subsection{African leaders and multinational corporations}

The most regrettable fact, as Ejiofor (1976:13 ff.) noted a long time ago, is that many African rulers trade-off their peoples to foreignbased multinational corporations that are said to be "unaccredited ambassadors of imperialistic super powers". There seems to be no doubt that the corporations still bribe those in key government positions to be able to cart away huge profits from the host country without opposition. As Ejiofor (1976:13) further notes, the much vaunted economic and social benefits brought-in by multinational corporations, such as the foreign oil companies, mobile phone and construction companies "are in reality Greek Gifts". Although this observation dates 1976, it seems standardly expressed, and unfortunately still current. Guest $(2005: 2)$ aptly notes that "Africa has endured its share of evil leaders", which is a confirmation of the fact that neither the North nor the Southern hemisphere has a monopoly of diabolically selfish leaders.

\subsection{The impact of bribery and corruption}

On the whole, bribery and corruption are said to constitute the bane of Africa's development. Kudadjie (2002:41) notes, for instance, that 
"many development projects have not materialized simply because of the poor and corrupt human factor". As he explains, "many governments have been corrupt, oppressive, and have violated fundamental human rights", which are due to "lack of serious ethical, social and political commitment, sensitivity, and probity". That, as Kudadjie concludes, "thwarted many development projects".

\subsection{The import of good leadership}

The implication seems to be that what is needed is a leadership that is patriotic, selfless, altruistic, honest and purposeful enough to wage war on corrupt policies and practices. The word leadership here refers to all those in decision-making and executive public positions. With that, Africa can be less afraid of globalisation, even when it is propagated by selfish multinational corporations and exploitative foreign imperial forces. Stiglitz (2002:37) explains that:

Botswana was helped by having diamonds, but countries like Congo Republic (formerly Zaire), Nigeria, and Sierra Leone were also rich in resources. In those countries, the wealth from this abundance fueled corruption and spawned privileged elites that engaged in internecine struggles for control of each country's wealth.

He explains Botswana's success further down the same page:

Part of the reason for this success was that the senior people in Botswana's government took great care in selecting their advisers. When the IMF offered to supply the Bank of Botswana with a deputy governor, the Bank of Botswana did not automatically accept him. The Bank's governor flew to Washington to interview him. He turned out to do a splendid job. Of course, no success is without blemishes. On another occasion, the Bank of Botswana allowed the IMF to pick somebody to be director of research, and that turned out, at least in the view of some, to be far less successful.

The lesson seems clear unequivocally: African leaders should take full responsibility for the running of the affairs of their countries; if they do, and they are ethically sound and prudent, the continent is not likely to have much problem with globalisation or any form of international relationship, be it bilateral or multilateral. That will constitute a good approach to globalisation, Afro-Biblically speaking. The ordinary citizens should make input by protesting and calling for change when necessary to engender good governance, in wholistic terms. 


\section{Conclusion}

This article discovers that globalisation, as a principle, conforms with Afro-Biblical worldviews, but only in so far as it embraces love for God and the neighbour. Both the Bible and ATR are said to enjoin unstinting love for God and the neighbour, universal justice, mercy and compassion.

It is, however, suspected that the owners of multinational corporations that are drumming up globalisation have ulterior motives. It was noted that Western institutions which the multinationals represent, have always sought for ways to exploit Africa, and the Third World in general. At the same time, there is the realisation that no external enemy could succeed without the cooperation of some internal enemy, and there have always been African rulers who collaborate with foreigners to exploit the continent. Bribery and corruption are perceived to be the real barriers to Africa's development and elimination of mass poverty. It is believed that with good and upright leadership, Africa can overcome the problems of bribery and corruption, and embrace the idea of globalisation with less trepidation. Such a leadership will have the requisite moral authority and the political will to stamp-out bribery and corruption internally, and resist whatever pressure might be emanating from any dubious external force. Leadership in this context does not refer to only the person occupying the number one position in a country, even though he/she is most crucial. Since a tree does not make a forest, leadership here refers to all those in decision-making and public executive positions. It is explicit in the Botswana example that is referred to. Leadership embraces all those in charge of different arms of government (the legislative, the executive, the judiciary) and the various parastatals. Good political leaders and civil servants could help to make globalisation conform with Afro-Biblical perspectives, or abort globalisation in respect of unholy deals. Of course, a lot can be said about the need for the general population to protest and call for change when necessary.

\section{List of references}

ANON. 2003. Ecowas report: Africa and globalisation. Sunday Champion: 15 Jun.

AWOLALU, J.O. \& DOPAMU, P.A. 2005. West African traditional religion. Ibadan: Macmillan.

BABU, A.M. 1976. Postscript. (In Rodney, Walter. How Europe underdeveloped Africa. Dar-es-Salaam: Tanzania Publishing House. p. 311-316.) 
BROWN, RAYMOND E. 1990. Response to 101 questions on the Bible. New York: Paulist.

BRUBAKER, PAMELA K. 2002. What price security? Echoes: justice, peace and creation news, 770.21. Geneva: World Council of Churches; cluster on Issues and Themes, Justice, Peace and Creation Team.

DALY, GABRIEL. 1996. Monogenism. (In Komonchak, Joseph A., Collins, Mary \& Lane, Dermot A., eds. The new dictionary of theology. Bangalore: Theological Publications. p. 673.)

EHUSANI, G.O. 1992. An afro-Christian vision: "Ozovehe": toward a more humanized world. Iprou-remo: Ambassador.

EJIOFOR, P.O.N. 1976. Multinational corporations as agents of imperialism. (In Onibonoje, G.O. Omotosho, Kole \& Lawal, O.A., eds. The indigenous for national development. Ibadan: Onibonoje. p. 11-24.)

EKWURU, E.G. 2000. The price of being human as an African in the contemporary world. Owerri: Totan.

FAJANA, A. \& BIGGS, B.J. 1967. Nigeria in history. Ibadan: Longmans.

FULLER, LOIS. 2001. A missionary handbook on African Traditional Religion. Bukuru: Africa Christian Textbooks.

GUEST, ROBER. 2005. The shackled continent: Africa's past, present and future. London: Macmillan.

IYEKOLO, E.B. 2006. The peoples of Okunland. Lagos: Concept Publications.

JOINET, B. 2000. The challenge of modernity in Africa. Nairobi: Paulines.

KOBIA, SAMUEL. 1998. The changing role of the state and the challenge for church leadership in Africa. Echoes: justice, peace and development news: no. 14. Geneva: World Council of Churches; programme Unit III on Justice, Peace and Creation.

KUDADJIE, JOSHUA N. 2002. Religion, morality and national development. (In Kudadjie, J.N., Ganusah, Rebecca Y. \& Alalade, Adekunle, eds. Religion, morality and West African society. Accra: West African Association of Theological Institutions. p. 31-53.)

MUSTAPHA, I.M. 2007. Hints on current affairs and general papers for promotion interviews. Oyo: Atarex Ventures.

NATIONAL CONFERENCE OF CATHOLIC BISHOPS. 1986. Economic justice for all: pastoral letter on Catholic social teaching and the U.S. economy. Washington D.C.: United States Catholic Conference.

NEWTON, ALEX. 1992. West Africa: a travel survival kit. Hawthorn: Lonely Planet.

NICHOLLS, B.J. 1998. Contextualization. (In Ferguson, Sinclair B. \& Wright, David F., eds. New dictionary of theology. Ontario: InterVarsity. p. 164167.)

PARSHALL, P. 2003. Muslim evangelism: contemporary approaches to contextualisation. Waynesboro: Gabriel.

PESCHKHE, HENRY C. 1981. Christian ethics: a presentation of special moral theology in the light of Vatican. Vol. 11. Alcester: Goodlife Neale.

RUELE, M.A. 2003. Facing the challenges of HIVIAIDS in Southern Africa: towards a theology of life. (In Dube, M.W., ed. HIVIAIDS in theological programmes. Geneva: World Council of Churches. p. 77-83.)

SHAIKH, K.M. 2006. Da'wah in modern times. New Delhi: Adam Publishers.

SHIELDS, NORMAN. 2004. Christian ethics. Bukuru: Africa Christian Textbooks. 
SMITH, READER \& SMITH, LACY BALDWIN. 1980. Essentials of world history. New York: Barron's Educational Series.

STIGLITZ, JOSEPH. 2002. Globalization and its discontents. New Delhi: Penguin.

TURAKI, YUSUFU. 2001. The unique Christ for salvation: the challenge of the non-Christian religions and cultures. Enugu: International Bible Society.

WARFIELD, B.B. 1988. Studies in theology. Pennsylvania: The Banner of Truth Trust.

WEBSTER'S ENCYCLOPEDIC UNABRIDGED DICTIONARY OF THE ENGLISH LANGUAGE. 1996. New York: Random House.

\section{Key concepts:}

African Traditional Religion (ATR)

corruption

culture

globalisation

International Monetary Fund (IMF)

Scripture

\section{Kernbegrippe:}

Bybel

globalisering

Internasionale Monetêre Fonds

korrupsie

kultuur

Tradisionele Afrikagelowe 